\title{
REFLECTION OF THE COINTEGRATION RELATION AMONG THE STOCK MARKETS ON THE PORTFOLIO CHOICES: AN EMPIRICAL APPLICATION FOR FRAGILE FIVE COUNTRIES
}

\author{
Gulfen Tuna*1 and Vedat Ender Tuna² \\ ${ }^{1}$ Sakarya University, Department of International Trade, Sakarya, Turkey \\ ${ }^{2}$ Sakarya University, Institute of Social Sciences, Sakarya, Turkey
}

\begin{abstract}
The aim of this study is to examine the long-term relationship between each pair of the countries separate from those in the Stock Markets of Fragile Five Countries and determine the optimal portfolio options for each of the BIITS countries according to the pieces of evidence obtained. Thus, the reflection of the concertedness among financial markets to the optimal portfolio options has been studied. Accordingly, long term relationships between each pair of BIITS countries have been investigated with monthly price value between June 2006 and July 2015 by means of Maki Cointegration Test. Optimal portfolio options have been established according to the Markowitz Model considering the long-term relationships between the markets. The pieces of evidence obtained show that lower-risk portfolios than the ones in their own national markets can be established in BIITS countries by applying international diversification.
\end{abstract}

Keywords: fragile five economies, portfolio diversification, Turkey, Maki Cointegration Test, portfolio selection

JEL Classification: G01, G11, C22

\section{INTRODUCTION}

The degree of the cointegration relation between financial markets is a crucial term for investors because investors, wishing to minimize total risk, can also use the cointegration relation as a means in international diversification in the same way as they

\footnotetext{
* Correspondence to: G. Tuna, Sakarya University, Department of International Trade, Esentepe Capus, Sakarya, Turkey; e-mail: geksi@sakarya.edu.tr
}

use the coefficient of correlation. As suggested in the portfolio theory, the risk level of the investor can be decreased by collecting financial assets with zero or negative correlation in the same portfolio. Also, when the financial instruments deprived of cointegration relation are collected in the same portfolio, the total portfolio risk can be decreased. In this way, the investor can also increase his likelihood to earn high income. Conversely, the fact that financial assets with positive correlation are present in the same portfolio can increase the total portfolio risk. Likewise, the fact 
that the financial instruments characterized by the cointegration relation are in the same portfolio also causes the risk of an increase. That is the reason why it is necessary that an investor in the financial market looking for new opportunities in international markets should be aware of the relationship of cointegration in order to generate high income. An investor able to collect the financial instruments of the markets deprived of any cointegration relation in his own portfolio also has a potential to earn high income. Finally, the fact that the financial instruments present in the markets with a high potential of cointegration, i.e. concertedness, are in the same portfolio also increases the investor's risk.

The most important question regarding an efficient portfolio diversification is what asset will be invested in and how much will be invested in that asset. Whereas the weight of each financial asset in the total portfolio is specified by means of the portfolio selection models, what asset is the right choice can be detected knowing the degree and the direction of the relationship among the assets. At this point, cointegration analyses are one of the most significant practices to determine the right choices in portfolio selection. K. Kasa (1992) stresses that cointegration is more meaningful for long-term investors.

Risk and income are two different portfolio selections that move in parallel. The investors who want to generate high income will inevitably be exposed to a high risk. At this point, whereas the markets with fluctuations are included in the high-risk group for investors, they have a potential to be the center of every investor's attention because they are also the markets where high income can be earned. This situation is also valid in connection with a reduction in the loss incurred. That the Federal Reserve decided to taper bonds on $22^{\text {nd }}$ May 2013 became a remarkable milestone for financial markets. In that period, Brazil, India, Indonesia, South Africa and Turkey had economies with high current deficits and inflation and a low growth rate. The expression "Fragile Five" was used to stand for these countries because of their fragile economies and close performances in a report prepared by Morgan Stanley on $1^{\text {st }}$ August 2013. Afterwards, the „BIITS“ acronym, which symbolizes the initial letters of the "Fragile Five" countries, was used on behalf of those economies.
In this study, the cointegration relationship among the stock markets of the countries: Brazil, India, Indonesia, Turkey and South Africa, which are assumed as the „Fragile Five“, has been investigated. In light of the pieces of evidence obtained, whether an investor in the BIITS countries could reduce risk by applying international diversification which he can perform via these markets in reference to his own national market has also been studied. This study is also thought to contribute to the literature in terms of whether those countries included in the risk group by Morgan Stanley are actually the areas of opportunities for investors.

This study is different from the studies in the present literature with respect to the methods it has employed. In portfolio diversifications, the relationship between either financial instruments or different markets is generally established by the cointegration analyses that do not allow structural breaks. However, in this study, whether the series are stable or not has been observed by means of the Carrion-i Slvestre Test, which allows five structural breaks. The cointegration relationship has been investigated via the Maki Cointegration Analysis, which takes into account structural breaks.

In line with this difference from the present literature, the study has been organized into six parts. According to this structure, the second part has been used for investigation into the literature and the models used have been summarized in the third part. In the fourth part, a data set has been studied and the pieces of evidence obtained have been presented in the fifth part. As for the last part, the evaluations have been made in accordance with the pieces of evidence obtained.

\section{LITERATURE REVIEW}

There are many studies in the present literature investigating the long-term relationship among the markets for both Turkey and other countries. R. W. Click and M. G. Plummer (2005) tested the cointegration relationship among Indonesia, Malaysia, Singapore and the Philippines by means of the weekly and daily data between 1998 and 2002. According to Johansen's, a cointegration test result used as the 
research model, there is a long-term relationship among all those countries.

E. Efendioğlu and D. Yörük (2005) studied the relationship between the stock markets of Turkey, Germany, France, England, Netherlands and Italy by using the monthly data between June 1993 and March 2005. According to the pieces of evidence obtained, there was no long-term relationship between Turkey and those countries in the period of the research.

N. B. Ceylan (2006) investigated the effects of the stock exchanges of the G-7 on the İstanbul Stock Exchange between 1988 and 2004. According to the results, it was found out that the İstanbul Stock Exchange, which was affected by the Japanese Stock Exchange to a limited extent, was also affected by all the other countries' stock exchanges.

S. Neamie (2006) studied the interaction of the Middle East and the North African countries and determined that Turkey was affected by the American and the English Stock Exchanges.

N. Egert and E. Kocenda (2007) observed the relationships between the European Financial Markets between 2003 and 2005. According to the data obtained, no cointegration relationship was found out between Central and East European countries. However, there was a cointegration relationship between West European countries.

Making use of the data about the base and the sectoral indices between 1986 and 2006, L. Çitak and O. Gözbaşı (2007) studied the long-term relationship between BIST and the stock exchanges of developing and developed countries. According to the research result, there is a long-term relationship between BIST and the stock markets of England, the USA, Germany and India.

T. Korkmaz and E. I. Çevik (2008) investigated the long-term relationship between the stock exchanges of Turkey and 12 developed and 22 developing countries using the monthly data between 1995 and 2007. According to the research result, BIST has a long-term relationship with the stock exchanges of developing countries: Czech Republic, Egypt, India, Israel and Taiwan, and the stock exchanges of developed countries: Australia, Canada, Germany, France, New Zealand, Switzerland and the USA.

E. Erbaykal, H. A. Okuyan and O. Kadıoğlu (2008) studied the cointegration relationship between the stock markets of BIST (Turkey), Bovespa (Brazil) and Merval (Argentina). According to the results of the research, which made use of the monthly data between 1997 and 2007, there was a long term equilibrium relationship between these three markets.

Making use of the monthly data between 1997 and 2008, M. Karğın (2008) studied the cointegration relationship between the stock markets of Turkey and 21 countries chosen from the Asian and the American continents. According to the results of this research, a meaningful cointegration relationship was found out between BIST 100 Index and the stock markets of only Brazil, Egypt and Mexico.

N. Küçükçolak (2008) studied the relationship between Turkey and the stock markets of England, Germany and France. Adding the stock market of Greece to his research, N. Küçükçolak used the daily data between January 2001 and December 2005. According to the results of the analysis carried out by means of the Engle-Granger Cointegration Test, no long-term relationship was found out between Turkey and other markets. That is the reason why it was advocated that an efficient portfolio diversification could be actualized through those countries.

E. Küçükkaya (2009) investigated the relationship between Turkey and America by means of the Johansen Cointegration Analysis, using the monthly data between May 1988 and May 2008. According to the pieces of evidence obtained, no relationship was found out between those two markets either in the short term or in the long-term. Therefore, it was precipitated that an efficient portfolio diversification could be made between those two markets.

T. Korkmaz, S. Zaman and E. I. Çevik (2009) analyzed the long term relationship between the stock markets of Turkey and developed and developing countries through cointegration tests with structural breaks. According to the results of this research, in which a monthly data set was used for the 1995-2007 period, it was found out that the stock markets of Turkey and 
16 developed and 21 developing countries concerted together in the long-term.

K. R. Chittedi (2009) studied the cointegration relationship between the stock markets of the BRIC countries and developed countries, such as the USA, England and Japan. According to the result of this research, carried out by using the daily data between January 1998 and August 2009, some findings supportive of the existence of a long term relationship between BRIC and developed countries were uncovered.

S. Bozoklu and I. M. Saydam (2010) studied the existence of integration between the capital markets of Turkey and the BRIC countries (Brazil, China, India, Russia) through the medium of the parametric Johansen (1988, 1991 and 1994) and the non-parametric Bierens (1997 and 2004) tests. According to the research results, they obtained the information that the capital markets of the studied countries were cointegrated.

O. Gözbaş1 (2010) investigated the interaction between the stock markets of BIST and Argentina, Brazil, Mexico, India, Malaysia, Hungary and Egypt. According to the research results, BIST has a long term relationship with the stock exchanges of Brazil, India and Egypt.

O. Taş and K. Tokmakçığlu (2010) analyzed whether the stock markets of 11 developing countries (Turkey, Brazil, Czech Republic, Egypt, Hungary, India, South Korea and Mexico) were concerted by means of the Johansen Cointegration Method using the weekly data set in the 1998-2008 period or not. According to the research results, the following information was obtained: the stock exchanges of the Czech Republic and India affect BIST in the same direction; the changes in the stock exchanges of Argentina, Indonesia and Hungary affect BIST in the reverse direction, whereas the Brazilian Stock Exchange affects the stock exchanges of Mexico, Israel and India in the same direction and the stock exchanges of South Korea, Indonesia and Hungary in the reverse direction.

B. Vuran (2010) came to the information related to the fact that the 100 Index of the İstanbul Stock Exchange had a long-term relationship with the FTSE 100 Index of England and the DAX Index of Germany.
This research was executed for the 2006-2009 period. Furthermore, the meaningful findings related to the fact that there was also a cointegration relationship between the stock markets of Turkey and the G-20 countries were obtained.

G. Tuna, V. E. Tuna and E. Bagirzade (2011) studied the existence of the long-term relationship between the stock markets of the USA, Greece and Turkey. According to the result of this research, carried out by means of the monthly data set between 2005 and 2009, the stock market of the USA and Greece had a longterm relationship with the Turkish stock market.

D. Boztosun and T. Çelik (2011) tested the long term relationship between the stock markets of Turkey, Austria, Belgium, France, Germany, the Netherlands, Norway, Spain, Sweden, Switzerland and England, using the monthly data in the 2002-2009 period. According to the results of the research carried out via the Johansen-Juselius Cointegration Test, the meaningful findings related to the fact that the Turkish stock markets had a cointegration relationship with the stock exchanges of Norway, the Netherlands, Belgium, Germany and England were obtained. However, no such relationship was found out to exist between France, Austria, Switzerland, Sweden and Spain.

Using the closing data of the stock market indices of the BIITS countries between November 2000 and December 2013, V. Akel (2015) studied the long-term relationship between the capital markets of these five countries. The pieces of evidence obtained were supportive of the fact that there was no long-term relationship between the stock markets of these countries.

As the studied literature works show, the cointegration degrees between the countries are actualized at different levels. Depending on each investor's risk exposure degree, this situation differently reflects on portfolio choices.

\section{THE MODEL}

In this research, the long-term relationship between the BIITS countries has been investigated through the 
Maki Cointegration Test. In accordance with the pieces of evidence obtained, portfolio choices have been studied under the constraint of making investments through international diversification in the securities markets that belong to only these countries. This process has been practiced separately for each country, starting from the Maki Cointegration Test as the basis. Investment in the countries that have a potential for high income may not be tempting for every investor because of its high risk in portfolio diversification. Here, we will search for an answer to the question of in what BIITS countries' market an investor yet willing to take this risk maximizes his/her profit.

In the research, the unit root and the existence of the long-term relationship have been studied by means of the Carrion-i Silvestre Test (2009) and the Maki Cointegration Test, respectively. The Optimal portfolio choices have been established according to the Markowitz Model.

\section{Carrion-i Silvestre Unit Root Test}

While the traditional Augmented Dickey Fuller (ADF) Unit Root Test does not take structural fractions, the Lumsdaine-Papel (LP) Unit Root Tests consider one or two structural fractions. J. L. Carrion-i Silvestre, D. Kim and P. Perron (2009) allows for five structural fractions at the most. Also, this test intrinsically determines fractions points. The test obtains fractions points by using the J. Bai and P. Perron (2003) Algorithm and with the help of the Quasi-GLS (Generalized Least Squares), the dynamic program process and minimizing the total of fault remnants. In this test technique, effective results can be obtained through small sampling (Carrion-i Silvestre et al, 2009). The stochastic data production process used in the test is as follows:

$y_{t}=d_{t}+u_{t}$

$u_{t}=a u_{t-1}+v_{t} \quad=0, \ldots \ldots \ldots \ldots \ldots \ldots \ldots . . T$

J. L. Carrion-i Silvestre et al, (2009) developed five different test statistics to test the stable nature of the sets:

$P_{t}\left(\lambda^{0}\right)=\left\{S\left(\bar{\alpha}, \lambda^{0}\right)-\bar{\alpha} S\left(1, \lambda^{0}\right)\right\} / s^{2}\left(\lambda^{0}\right)$
$M P_{T}\left(\lambda^{0}\right)=\left[c^{-2} T^{-2} \sum_{t=1}^{T} \tilde{y}_{t-1}^{2}+(1-\tilde{c}) T^{-1} \tilde{y}_{T}^{2}\right] / s\left(\lambda^{0}\right)^{2}$

$M Z_{\alpha}\left(\lambda^{0}\right)=\left(T^{-1} \tilde{y}_{T}^{2}-s\left(\lambda^{0}\right)^{2}\right)\left(2 T^{-2} \sum_{t=1}^{T} \tilde{y}_{t-1}^{2}\right)^{-1}$

$\operatorname{MSB}\left(\lambda^{0}\right)=\left(s\left(\lambda^{0}\right)^{-2} T^{-2} \sum_{t=1}^{T} \tilde{y}_{t-1}^{2}\right)^{-\frac{1}{2}}$

$M Z_{t}\left(\lambda^{0}\right)=\left(T^{-1} \tilde{y}_{T}^{2}-s\left(\lambda^{0}\right)^{2}\right)\left(4 s\left(\lambda^{0}\right)^{2} T^{-2} \sum_{t=1}^{T} \tilde{y}_{t-1}^{2}\right)^{-\frac{1}{2}}$

The hypotheses of the test:

H0: There is a unit root under structural fractions.

H1: There is no unit root under structural fractions.

The asymptotic values necessary for testing these hypotheses are produced by bootstrap. When the calculated test statistics are less than the critical value, the $\mathrm{H} 0$ hypothesis is rejected. When there is a structural fraction in the set, the new set is found to be stable and there is no unit root (Göçer \& Peker, 2014).

\section{The Maki Cointegration Test}

Cointegration tests studying the existence of a longterm relationship could give bias results in a series where structural breaks are present (Gregory \& Hansen, 1996). For that reason, it is important to apply the cointegration tests that take into account the effects of structural breaks in terms of efficient results. Thus, in the research, the long-term relationship has been studied through the Maki (2012) Test, which is able to take up to five structural breaks. In the Maki Test, all the series in which the long-term relationship will be investigated are required to be $i(1)$. In the Maki Test, structural break points are internally determined. Each period is considered as a possible break point; the $t$ statistics are calculated and the minimum points of the $t$ statistics are considered to be the break points. D. Maki has developed four test models (Göçer \& Peker, 2014):

Model 0: where there is a refracture in the constant term, the model without a trend: 
$y_{t}=\mu+\sum_{i=1}^{k} \mu_{i} K_{i, t}+\beta x_{t}+u_{t}$

Model 1: there is a refracture in the constant term and in the grade, the model without a trend:

$y_{t}=\mu+\sum_{i=1}^{k} \mu_{i} K_{i, t}+\beta x_{t}+u_{t}+\sum_{i=1}^{k} \beta_{i} x_{i} K_{i, t}+u_{t}$

Model 2: there is a refracture in the constant term and in the grade, the model with a trend:

$y_{t}=\mu+\sum_{i=1}^{k} \mu_{i} K_{i, t}+\gamma x+\beta x_{t}+\sum_{i=1}^{k} \beta_{i} x_{i} K_{i, t}+u_{t}$

Model 3: there is a refracture in the constant term and in the grade and in the trend, too.

$$
\begin{aligned}
& \boldsymbol{y}_{t}=\mu+\sum_{i=1}^{k} \mu_{i} K_{i, t}+\gamma \boldsymbol{x}+\sum_{i=1}^{k} \gamma_{i} t K_{i, t}+\beta \boldsymbol{x}_{t}+ \\
& +\sum_{i=1}^{k} \beta_{i} \boldsymbol{x}_{i} K_{i, t} \boldsymbol{u}_{z}
\end{aligned}
$$

$K_{i}$ is the dummy variable and D. Maki (2012) describes it in the following manner:

$K_{i}= \begin{cases}1 & t>T_{B} \quad \text { while } \\ 0 & \text { in other cases }\end{cases}$

Here, the TB expresses the date of the structural breaks. The hypotheses of the test:

H0: There is no cointegration relationship under structural breaks between the series.

H1: There is a cointegration relationship under structural breaks between the series.

In this study, the evaluations have been carried out by means of Model 3.

\section{The Markowitz Portfolio Selection Model}

Taking the H. Markowitz (1952) Model as the basis, we have tried to determine portfolio choices. In this case, the total portfolio return is expressed as:
$E\left(r_{p}\right)=\sum_{i=1}^{N} x_{i} r_{i}$

The total portfolio risk is as follows:

$\sigma_{p}^{2}=\sum_{i=1}^{N} \sum_{j=1}^{N} X_{i} X_{j} \sigma_{i j}$

Here, $N$ stands for the number of the securities included in the portfolio. $X_{i}$ is the parameter representing the weight of the $i$ asset in the portfolio. While the $r_{i}$ represents the expected return of the $i$ asset, ", $\delta_{i j}$ " stands for the covariance value between the assets $i$ and $j$. The model used in portfolio selection is as listed below and we have tried to determine the stock markets present in portfolios with the minimum standard deviation.

Objective Function

$\min \left(\sigma_{p}^{2}\right)=\sum_{i=1}^{N} \sum_{j=1}^{N} X_{i} X_{j} \sigma_{i j}$

Constraints

$\sum_{i=1}^{N} X_{i}=1$

$X_{i} \geq 0, \forall X_{i} \in[i=1,2, \ldots, N]$

\section{THE DATA}

The monthly closing prices for the indices used on behalf of the BIITS countries for the period between June 2006 and July 2015 have been used as the data set in this research. The indices used on behalf of the securities markets of the BIITS countries are accounted for in Table 1.

The basic statistical values that belong to the indices used on behalf of the stock markets of the BIITS countries are as shown in Table 2.

In the studied period, the stock markets of all the BIITS countries offered positive return to their investors. Among these countries, Indonesia had the most risky stock market and Brazil had the least risky one. 
The correlation values made up in order to be able to determine the direction and degree of the relationship between these markets are as presented in Table 3 .

According to the results obtained from the correlation matrix, we can talk about the negative relationship between the stock markets of South Africa and India. As for the correlation coefficients, the fact that South African and Indian stocks are gathered in the same portfolio can reduce the risk. As to the stock markets of the other countries, they have positive correlations. Indonesia and India have the lowest

Table 1 The stock market indices for the BIITS economies

\begin{tabular}{l|ll}
\hline Country & Stock Market Index & Index Code \\
\hline South Africa & FTSE Johannesburg Stock Market Index & JSE \\
Brazil & Sao Paulo Stock Market Index & BVSP \\
Indonesia & Jakarta Stock Exchange Composite Index & JKSE \\
India & S\&P Bombay Stock Exchange Index & SNSX \\
Turkey & Borsa İstanbul 100 Index & BIST \\
\hline
\end{tabular}

Source: Authors

Table 2 Descriptive statistics

\begin{tabular}{l|ccccc}
\hline & $\begin{array}{c}\text { JSE } \\
\text { (South Africa) }\end{array}$ & $\begin{array}{c}\text { BVSP } \\
\text { (Brazil) }\end{array}$ & $\begin{array}{c}\text { JKSE } \\
\text { (Indonesia) }\end{array}$ & $\begin{array}{c}\text { SNSX } \\
\text { (India) }\end{array}$ & $\begin{array}{c}\text { BIST } \\
\text { (Turkey) }\end{array}$ \\
\hline Mean & 0.018 & 0.002 & 0.012 & 0.008 & 0.009 \\
Median & 0.012 & 0.005 & 0.016 & 0.00 & 0.008 \\
Maximum & 0.317 & 0.144 & 4.663 & 2.507 & 0.213 \\
Minimum & -0.273 & -0.211 & -4.587 & -2.162 & -0.262 \\
Std. Dev. & 0.091 & 0.064 & 1.086 & 0.326 & 0.080 \\
Skewness & 0.020 & -0.466 & 0.052 & 1.432 & -0.419 \\
Kurtosis & 4.656 & 3.621 & 9.114 & 50.52 & 3.634 \\
\hline
\end{tabular}

Source: Authors

Table 3 The correlation matrix for the BIITS countries

\begin{tabular}{l|ccccc}
\hline & JSE & BVSP & JKSE & SNSX & BIST \\
& (South Africa) & (Brazil) & (Indonesia) & (India) & (Turkey) \\
\hline JSE(South Africa) & 1 & 0.39 & 0.06 & -0.08 & 0.32 \\
BVSP (Brazil) & 0.39 & 1 & 0.12 & 0.10 & 0.54 \\
JKSE (Indonesia) & 0.06 & 0.12 & 1 & 0.03 & 0.15 \\
SNSX (India) & -0.08 & 0.10 & 0.03 & 1 & 0.05 \\
BIST (Turkey) & 0.32 & 0.54 & 0.15 & 0.05 & 1 \\
\hline
\end{tabular}


positive correlation coefficient. Turkey and Brazil have the highest positive correlation coefficient. In this case, whereas the securities markets of India and South Africa can each be said to be a good means of portfolio diversification for each other, on the one hand, they are not so good in that respect for the other countries.

\section{THE EMPIRICAL RESULTS}

The results of the Carrion-i Silvestre (2009) Unit Root Test, which allows five structural breaks for the studied stock markets, are as follows (Table 4).

Table 4 The results of the Carrion-i Silvestre Unit Root Tests

\begin{tabular}{|c|c|c|c|c|c|}
\hline \multicolumn{4}{|r|}{ Level } & \multicolumn{2}{|c|}{$\begin{array}{c}1^{\text {st }} \\
\text { Difference }\end{array}$} \\
\hline & $\begin{array}{l}\text { Test } \\
\text { Stat. }\end{array}$ & C. Values & Breaking Time & $\begin{array}{l}\text { Test } \\
\text { Stat. }\end{array}$ & C. Values \\
\hline \multicolumn{6}{|c|}{ BVSP } \\
\hline $\mathrm{PT}_{\mathrm{T}}$ & 10.131 & 8.363 & July2014 & 3.104 & 5.217 \\
\hline $\mathrm{MPr}$ & 9.567 & 8.363 & January 2012 & 2.871 & 5.217 \\
\hline $\mathrm{MZ}_{\alpha}$ & -40.737 & -45.867 & February 2011 & -40.581 & -21.420 \\
\hline MSB & 0.110 & 0.103 & August 2009 & 0.110 & 0.152 \\
\hline $\mathrm{MZ}_{\mathrm{t}}$ & -4.510 & -4.800 & April 2008 & -4.504 & -3.320 \\
\hline \multicolumn{6}{|c|}{ JSE } \\
\hline $\mathrm{PT}_{\mathrm{T}}$ & 18.523 & 8.866 & October 2014 & 4.285 & 6.606 \\
\hline $\operatorname{MPr}$ & 15.429 & 8.866 & November 2013 & 4.250 & 6.606 \\
\hline $\mathrm{MZ}_{\alpha}$ & -24.944 & -43.425 & September 2009 & -53.311 & -32.463 \\
\hline MSB & 0.141 & 0.107 & September 2008 & 0.096 & 0.125 \\
\hline $\mathrm{MZ}_{4}$ & -3.531 & -4.643 & July2007 & -5.124 & -4.018 \\
\hline \multicolumn{6}{|c|}{ JKSE } \\
\hline$\overline{P_{\gamma}}$ & $9 \cdot 914$ & 9.350 & April 2014 & 2.921 & $5.75 a$ \\
\hline $\mathrm{MPT}$ & 8.903 & 9.350 & April 2013 & 2.950 & $5.75 a$ \\
\hline $\mathrm{MZ}_{\alpha}$ & -50.584 & -47.554 & June 2011 & -54.496 & -27.868 \\
\hline MSB & 0.099 & 0.102 & July2010 & 0.095 & 0.136 \\
\hline $\mathrm{MZ}_{\mathrm{t}}$ & -5.028 & -4.852 & August2008 & -5.217 & -3.707 \\
\hline \multicolumn{6}{|c|}{ SENSEX } \\
\hline PT & 17.248 & 8.935 & September 2014 & 3.223 & 5.244 \\
\hline $\mathrm{MPr}$ & 14.983 & 8.935 & September 2013 & 2.977 & 5.244 \\
\hline $\mathrm{MZ}_{\alpha}$ & -27.151 & -45.274 & June 2010 & -47.932 & -24.721 \\
\hline MSB & 0.135 & 0.104 & May 2009 & 0.101 & 0.144 \\
\hline $\mathrm{MZ}_{\mathrm{t}}$ & -3.684 & -4.750 & November 2007 & -4.862 & -3.519 \\
\hline \multicolumn{6}{|c|}{ BIST } \\
\hline PT & 12.550 & 9.124 & January 2013 & 5.505 & 5.348 \\
\hline $\mathrm{MPr}$ & 12.313 & 9.124 & September 2011 & 5.172 & 5.348 \\
\hline $\mathrm{MZ}_{\alpha}$ & -34.604 & -45.889 & May 2010 & -28.454 & -26.587 \\
\hline MSB & 0.120 & 0.104 & March 2009 & 0.132 & 0.139 \\
\hline $\mathrm{MZ}$ & -4.158 & -4.781 & November 2007 & -3.769 & -3.646 \\
\hline
\end{tabular}

Note: $\% 5$ expresses the stability at the significance level. Structural break dates are the dates determined by the test method.

Source: Authors
According to the results of the CS Unit Root Test, the obtained test statistics are larger than the critical values. This situation shows that all the series have the unit root at the fundamental level. However, given the differences at the first degree, all the series come to a standstill.

Since all the series contain the unit root according to different criteria at their fundamental level and since they let up when the first difference is taken, it will be possible to apply cointegration tests. The results of the Maki Cointegration Test, studying the existence of the long-term relationship between the stock markets of the BIITS countries, are given in Table 5.

All the test statistics calculated for the İstanbul Stock Exchange are larger than the critical values. Such a result promotes the fact that there is no long-term relationship between the İstanbul Stock Exchange and the stock markets of the other BIITS countries. In other words, the stock markets of BIST and the other BIITS countries are not concerted in the long run. Therefore, all these countries are a good means of portfolio diversification for BIST.

All the test statistics calculated for the JKSE and the SNSX are smaller than the critical values. In such a situation, according to the results of the cointegration analysis carried out for the JKSE and the SNSX, there is a cointegration relationship between these countries and the other BIITS countries. Therefore, the stock exchanges of the JKSE and the SNSX can be said to be concerting with the other BIITS stock exchanges in the long run. Also, in this situation, the stock markets of the other BIITS countries are not a good means of portfolio diversification not only for the JKSE, but also for the SNSX. According to the findings obtained through comparing the calculated test statistics with the critical values, the SNSX is a good portfolio diversification means for the JSE and as far as the BVSP, the JSE and the JKSE are concerned, they are good portfolio diversification means. Establishing an optimal portfolio for the JKSE and the SNSX via the stock markets of the other BIITS countries is not possible. Whereas the other four countries can be included in the optimal portfolio for BIST, the JSE can establish an efficient portfolio only with the SNSX, whereas the BSVP can do so with the JSE and the 
JKSE, because a long-term relationship is no matter of discussion among these countries. According to these pieces of evidence, the portfolio choices formed according to the Markowitz Model in the markets which have no long-term relationship are as accounted for in Table 6.

Table 5 The results of the Maki Cointegration Test

\begin{tabular}{|c|c|c|c|}
\hline & & $\begin{array}{r}\text { Test } \\
\text { Statistics }\end{array}$ & Breaking Dates \\
\hline \multirow{4}{*}{$\frac{\mathfrak{n}}{\infty}$} & JKSE & $-5.944(6.712)$ & March 2013, September 2009, October 2008, February 2008 \\
\hline & JSE & $-6.274(6.712)$ & January 2011, June 2009, August 2008, October 2007 \\
\hline & BVSP & $-4.437(-6,267)$ & November 2012, March 2010, June 2009 \\
\hline & SNSX & $-7.015(7.110)$ & January 2014, March 2013, January 2011, May 2009, February 2008 \\
\hline \multirow{4}{*}{$\begin{array}{l}\text { 崩 } \\
\text { 극 }\end{array}$} & BIST & $-11.966 *(-6,267)$ & February 2014, February 2013, December 2006 \\
\hline & JSE & $-14.441^{*}(7.110)$ & May 2013, May 2011, October 2010, April 2008, December 2006 \\
\hline & BVSP & $-12.231 *(6.712)$ & March 2013, March 2011, July 2008, December 2006 \\
\hline & SNSX & $-13.710 *(7.110)$ & March 2014, March 2013, January 2011, July 2008, December 2006 \\
\hline \multirow{4}{*}{ 峁 } & BIST & $-7.113^{*}(7.110)$ & January 2013, February 2010, December 2008, January 2008, June 2007 \\
\hline & JKSE & $-7.395^{*}(7.110)$ & January 2013, March 2011, July 2009, July 2008, June 2007 \\
\hline & BVSP & $-6.760 *(-6,267)$ & January 2013, August 2008, December 2006 \\
\hline & SNSX & $-6.393(7.110)$ & June 2014, January 2013, October 2009, April 2009, June 2007 \\
\hline \multirow{4}{*}{$\stackrel{n}{n}$} & BIST & $-6.874 *(6.712)$ & May 2013, September 2010, November 2009, July 2008 \\
\hline & JKSE & $-6.252(-6,267)$ & November 2012, February 2012, January 2008 \\
\hline & JSE & $-5.794(-6,267)$ & December 2014, December 2012, January 2011 \\
\hline & SNSX & $-6.605^{*}(-6,267)$ & November 2009, April 2009, April 2008 \\
\hline \multirow{4}{*}{ 肴 } & BIST & $-13 \cdot 549 *(-5,485)$ & July 2012, April 2009 \\
\hline & JKSE & $-9.711^{*}(-5,485)$ & May 2009 , October 2008 \\
\hline & JSE & $-16.412 *(-5,485)$ & June 2009, November 2008 \\
\hline & BVSP & $-11.323^{*}(-5,281)$ & April 2009 \\
\hline
\end{tabular}

Note: * \%10 expresses that the test statistics are meaningful at the confidence level

Source: Authors

According to the obtained pieces of evidence, only four stock markets have been included for BIST investors in the optimal portfolios formed according to the Markowitz Model. Although there is no relationship between BIST and the BVSP in the long run, that market has not been included in the optimal portfolio. When it comes to investment in only the domestic market of BIST, \% 8.0598 risk is borne, whereas \% 0.9152 return is acquired. However, when the optimal portfolio determined for the BIST investor and listed in Table 6, in which international diversification is in question, is invested in, risk regresses to $\% 5.852$, whereas return rises to $\% 1.068$. According to the obtained pieces of evidence obtained, the BIST investor establishes a portfolio which is both less risky and more profitable in comparison with the internationally diversified portfolio established via the securities markets of the BIIST countries and his investment in the domestic market.

The optimal portfolio for JSE investors has only been implemented through the SNSX Stock Market, in which no long-term relationship is present. When investment in only the domestic market of the JSE is concerned, \% 9.1962 risk is borne, whereas $\% 1.8051$ return is acquired. However, when the optimal portfolio determined for the JSE investor and listed in Table 6, in which international diversification is in question, is invested in, return regresses to $\% 0.879$ and risk also regresses to $\%$ 6.113. Through international diversification, the JSE investor is able to reduce risk considerably. 
There are merely two stock markets in the optimal portfolio of the BVSP investor in which no longterm relationship is present. Yet, the BVSP market is not included in the optimal portfolio at all. When investment in only the domestic market of the BVSP is concerned, \% 6.4104 risk is borne, whereas $\% 0.2715$ return is acquired. However, when the optimal portfolio determined for the BVSP investor and listed in Table 6, in which international diversification is in question, is invested in, risk regresses to \% 6.353, whereas $\% 0.2715$ return is acquired. In this market, there are also both a considerable amount of return growth and risk reduction through international diversification. Consequently, whereas a substantial amount of risk reduction could be accomplished in all the stock markets through international diversification, return growth could only be ensured for BIST and the BVSP. This is also verified by the coefficients of

Table 6 Portfolio allocation

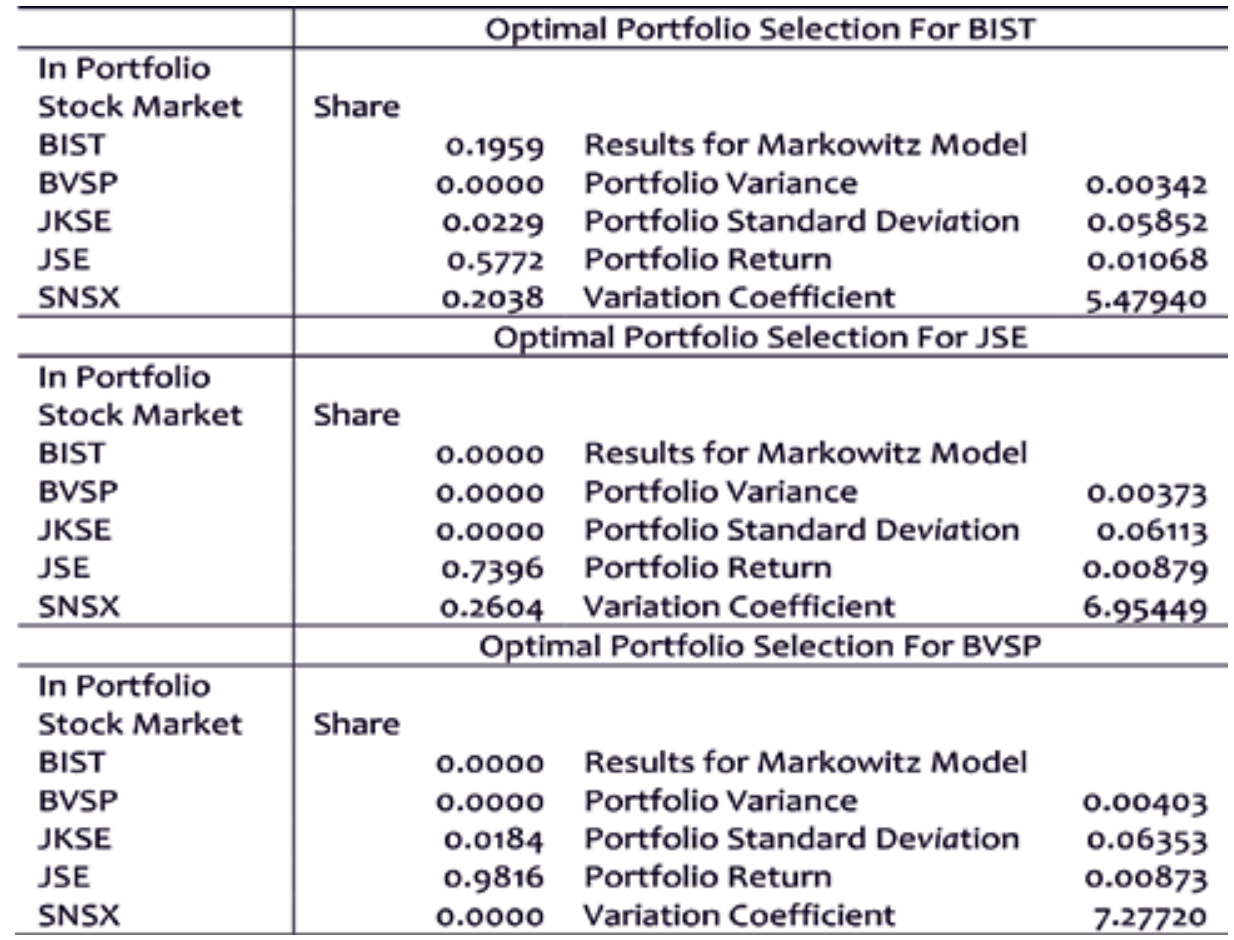

Source: Authors

variation. The coefficients of variation, showing the risk levels borne for a unit of return, have lessened for the BVSP and BIST compared to their domestic markets. This fact means that the risk level that will be borne by BIST and BVSP investors for one unit of return growth through international diversification will lessen.

\section{CONCLUSION}

Portfolio diversification is a highly important concept in terms of a reduction in non-systematic risk in financial markets. Any investor wishing to reduce the total portfolio risk must gather such financial assets that are either zero - or negatively correlated or such that are deprived of any long-term relationship between them in the same portfolio.

The BIITS countries are considered as high-risk markets in the finance literature because of their high inflation and current deficits. Yet, high risk could also bring about an opportunity for high returns. At this point, these markets may be appealing to the investors who like taking risks and who want to acquire high returns. In this study, the existence of the long-term relationships 
between and among the BIITS countries has been investigated separately for each pair of countries for the 2006:06 - 2015:07 period and the optimal portfolio choices have been determined by applying the obtained pieces of evidence as the basis. According to the pieces of evidence obtained from the optimal portfolio choices for BIST, the JSE and the BVSP, a substantial amount of risk reduction has been accomplished for all the three countries compared to their domestic markets by means of international diversification. This also shows that if the securities markets belonging to the high-risk group can be included in the portfolio options in correct proportions, the total portfolio risk can be reduced. In other words, it shows that an investor who utilizes international diversification and takes into account the long-term relationship between the BIITS countries may be exposed to a low risk and simultaneously acquire high return compared to his own domestic stock market.

This research shows that, when there is an efficient portfolio, the stock markets involved in the high-risk group can be diversified by high-risk stock markets for investors. This situation demonstrates the importance of international portfolio diversification. In this study, however, the optimal portfolios have only been made for the stock markets of the fragile five countries that belong to the high-risk group. The paper does not take into account the international stock market outside the stock markets of the fragile five countries, which is the crucial constraint of the research. In future studies, the number of the countries included in the research can be increased and panel data analysis techniques can be used for further studies. Thus, the generalizability of the obtained results will also increase.

\section{REFERENCES}

Akel, V. (2015). Kırılgan Beşli Ülkelerinin hisse senedi piyasaları arasındaki eşbütünleşme analizi int. Journal of Management Economics and Business, 11(24), 75-96. doi. org/10.17130/ijmeb.2015.11.24.719

Bai, J., \& Perron, P. (2003). Critical values for multiple structural change tests. The Econometrics Journal, 6(1), 72-78. doi: 10.1111/1368-423X.00102

Bozoklu, Ş., \& Saydam, İ. M. (2010). BRIC Ülkeleri ve Türkiye arasındaki sermaye piyasaları entegrasyonunun parametrik ve parametrik olmayan eşbütünleşme testleri ile analizi. Maliye Dergisi, 159, 416-431.

Boztosun, D., \& Çelik, T. (2011). Türkiye borsasının avrupa borsaları ile eşbütünleşme analizi. The Journal of Faculty of Economics and Administrative Sciences, 16(1), 147-162.

Carrion-i-Sylvestre, J. L., Kim, D., \& Perron, P. (2009). GLSBased unit root tests with multiple structural breaks under both the null and the alternative hypotheses. Econometric Theory, 25(6), 1754-1792. doi.org/10.1017/S0266466609990326

Ceylan, N. B. (2006). G-7 Ülkelerinin borsalarının İstanbul menkul kıymetler borsası üzerindeki etkileri. IMKB Dergisi, $8(32), 37-55$

Chittedi, K. R. (2010). Global stock markets development and integration: With special reference to BRIC countries. International Review of Applied Financial Issues \& Economics, 2(1).

Click, R. W., \& Plummer, M. G. (2005). Stock market integration in ASEAN after the Asian financial crisis. Journal of Asian Economics, 16(1), 5-28. doi.org/10.1016/j.asieco.2004.11.018

Çıtak, L., \& Gözbaşı, O. (2007). İMKB İle bazı önde gelen gelişmiş ve gelişmekte olan ülke borsaları arasındaki bütünleşmenin temel endeks veya ana sektör endeksleri temelinde analizi. Dokuz Eylül Üniversitesi Iktisadi ve İdari Bilimler Fakültesi Dergisi, 22(2), 249-271.

Efendioğlu, E., \& Yörük, D. (2005). Avrupa birliği sürecinde Türk hisse senedi piyasası ile avrupa birliği hisse senedi piyasalarının bütünleşmesi. İMKB Örneği. Unpublished Working Paper.

Égert, B., \& Kocenda, E. (2007). Time-varying comovements in developed and European stock markets: Evidence from intraday data. William Davidson Institute Working Paper No. 861.

Erbaykal, E.,Okuyan, H. A.\& Kadıŏglu,Ö. (2008). Cointegration and priority relationships between stock markets of Turkey, Brazil and Argentina. European Journal of Economics, Finance and Administrative Sciences, 10, 151-158.

Göçer, İ., \& Peker, O. (2014). Yabancı doğrudan yatırımların istihdam üzerindeki etkisi: Türkiye, çin ve hindistan örneğinde çoklu yapısal kırılmalı eşbütünleşme analizi. Yönetim ve Ekonomi: Celal Bayar Üniversitesi İktisadi ve İdari Bilimler Fakültesi Dergisi, 21(1), 107-123. doi: 10.18657/ yecbu. 24019

Gözbaşı, O. (2010). İMKB ile gelişmekte olan ülkelerin hisse senedi piyasalarının etkileşimi: Eşbütünleşme ve nedensellik yaklaşımı. Erciyes Üniversitesi İktisadi ve İdari Bilimler Fakültesi Dergisi, 100(35), 99-118. 
Gregory, A. W., \& Hansen, B. E. (1996). Residual-based tests for cointegration in models with regime shifts. Journal of Econometrics, 70(1), 99-126. doi.org/10.1016/03044076(69)41685-7

Karğın, M. (2008). Hisse senedi piyasalarında eşbütünleşme analizi. Finans Politik \& Ekonomik Yorumlar, 45(525), 85-96.

Kasa, K. (1992). Common stochastic trends in international stock markets. Journal of Monetary Economics, 29(1), 95-124. doi:10.1016/0304-3932(92)90025-W

Korkmaz, T., \& Çevik, E. İ. (2008). Türkiye ve uluslararası hisse senedi piyasaları arasındaki eşbütünleşme ilişkisi ve portföy tercihleri. BDDK Bankacillk ve Finansal Piyasalar, 2(1), 59-84.

Korkmaz, T., Zaman, S., \& Çevik, E. İ. (2009). İMKB ile uluslar arası hisse senedi piyasaları arasındaki entegrasyon ilişkisinin yapısal kırılma testleri ile analizi. Akdeniz IİBF Dergisi, 17, 40-71.

Küçükçolak, N. (2008). Co-Integration of the Turkish Equity market with Greek and other EU equity market. International Research Journal of Finance and Economies, (13).

Küçükkaya, E. (2009). Diversification benefits of including Turkish and US stocks in a portfolio. The International Journal of Economic and Social Research, 5(2), 1-11.

Maki, D. (2012). Tests for cointegration allowing for an unknown Number of Breaks. Economic Modelling, 29(5), 20112015. doi.org/10.1016/j.econmod.2012.04.022

Markowitz, H. (1952). Portfolio selection*. The journal of finance, 7(1), 77-91.

Neaime, S. (2006). Volatilities in emerging MENA stock markets. Thunderbird International Business Review, 48(4), 455484. do1: 10.1002/tie.20105

Taş, O., \& Tokmakçıŏlu, K. (2010). Efficient market hypothesis and comovement among emerging markets. Dogus University Journal, 11(2), 286-301.

Tuna, G, Tuna, V. E., \& Bağırzade, E. (2011). Uluslararası hisse senedi piyasaları arasındaki nedensellik ilişkisi: Türkiye, Yunanistan ve Amerika üzerine ampirik bir uygulama. Azerbaycan Vergi Haberleri Dergisi, 6, 73-86.

Vuran, B. (2010). IMKB 100 endeksinin uluslararası hisse senedi endeksleri ile ilişkisinin eşbütünleşim analizi ile belirlenmesi. Istanbul University Journal of the School of Business Administration, 39(1), 154-168.

Received on $12^{\text {th }}$ December 2016, after revision, accepted for publication on $26^{\text {th }}$ December 2016.

Published online on $30^{\text {th }}$ December 2016.

Gulfen Tuna is an Associate Professor at the Faculty of Management, Sakarya University, Sakarya, Turkey. She received her PhD in Finance. Her research interests include portfolio management, risk management, corporate governance.

Vedat Ender Tuna is a sworn-in certified public accountant at Sakarya, Turkey. He obtained his $\mathrm{PhD}$ in Accounting. His interests include IFRS, tax advisory, independent audit, corporate tax compliance, costbenefit analysis. 


\title{
ODRAZ ODNOSA KOINTEGRACIJE MEĐU BERZAMA NA IZBOR PORTFOLIJA: EMPIRIJSKA PRIMENA ZA FRAGILNIH PET ZEMALJA
}

\author{
Gulfen Tuna' and Vedat Ender Tuna ${ }^{2}$ \\ 'Sakarya University, Department of International Trade, Sakarya, Turkey \\ ${ }^{2}$ Sakarya University, Institute of Social Sciences, Sakarya, Turkey
}

\begin{abstract}
Ova studija ima za cilj da ispita dugoročni odnos između svakog para zemalja odvojeno od onih na berzama fragilnih pet zemalja i da utvrdi opcije optimalnog portfolija za svaku od zemalja iz grupe BIITS u skladu sa pribavljenim dokazima. Na taj način, proučava se odraz koordiniranosti među finansijskim tržištima na opcije optimalnog portfolija. U skladu sa tim, pomoću Makijevog testa kointegracije, istražuju se dugoročni odnosi između svakog para zemalja iz grupe BIITS sa vrednošću cena na mesečnom nivou, u periodu jun 2006 - jul 2015. Opcije optimalnog portfolija uspostavljaju se u skladu sa Markovicevim modelom, koji razmatra dugoročne odnose između tržišta. Dobijeni dokazi ukazuju na to da zemlje iz grupe BIITS mogu diversifikacijom svojih portfolija na međunarodnom nivou ustanoviti svoja sopstvena portfolija, koja su nižeg rizika od portfolija na njihovim domaćim tržištima.
\end{abstract}

Ključne reči: fragilnih pet ekonomija, diversifikacija portfolija, Turska, Makijev test kointegracije, izbor portfolija

JEL Classification: G01, G11, C22 